\title{
Syntheses and Plant Growth-regulating Activity of 2-Substituted Phenylacetic Acid Derivatives
}

\author{
Katsuji Watanabe and Eiji TANiguchi* \\ Department of Agricultural Chemistry, Faculty of Agriculture, Kyushu University, \\ Hakozaki 6-10-1, Higashiku, Fukuoka 812, Japan
}

Received February 10, 1986

\begin{abstract}
Several derivatives of 2-(1',3'-dioxo-3'-phenylpropyl)phenylacetic acid, a homolog of the auxin transport inhibitor 2-(1',3'-dioxo-3'-phenylpropyl)benzoic acid (CPD), were synthesized. The phenylacetic acids with a heterocyclic ring such as isoxazole between the two phenyl groups inhibited the growth of lettuce, rice, and buckwheat. They prevented the active movement of auxin within the bean segments and abolished the root geotropic response of lettuce seedlings, as well as auxin transport-inhibiting benzoic acids. These phenylacetic acids may be intrinsic inhibitors of auxin transport.
\end{abstract}

A variety of chemicals which prevent the active movement of auxin in plant tissues also have the additional physiological properties of retarding the growth of stem and root and abolishing the root and stem geotropic resposes, photoresponse, and the apical dominance effect. ${ }^{1 \sim 4)}$ For a class of chemicals having antigeotropic activity, a common set of chemical requirements were defined ${ }^{5)}$ and these requirements were at least similar to those which cause inhibition of auxin transport, ${ }^{6}$ ) although the nature of the relationship between these physiological processes is yet to be defined. The ortho-substituted benzoic acids such as CPD, CPP, DPX-1840, and NPA, which are known as highly active auxin transport inhibitors, fulfill these requirements.

In the course of investigation of the biological activities of isochroman-3-ones, we found that phenacylideneisochroman-3-one, which has a similar structure to CPD, abolished the geotropic response of roots of lettuce seedlings. Simple derivatives of phenylacetic acid, whose lactone is isochroman-3one, were active in a number of tests for plant growth regulators of the auxin type ${ }^{7)}$ and also were isolated as phytotoxins of plant pathogens. ${ }^{8)}$

During our work on the isochroman-3-ones, a set of phenylacetic acid derivatives corresponding to known auxin transport-inhibiting benzoic acids were synthesized and their physiological properties and potentialities of auxin transport inhibitors were assessed on the growth of lettuce, rice, and buckwheat, and then on the auxin transport within bean stem sections.

\section{Syntheses}

The phenylacetic acids tested were synthesized according to the route shown in Figs. 1 and 2.

Benzaldehyde was condensed with 2-acetylphenylacetic acid in the presence of sodium hydroxide to give 2-cinnamoylphenylacetic acid 1, which furnished 2-( $\alpha, \beta$-dibromophenylpropionyl)phenylacetic acid by bromination. Compounds, 2 and 3, were obtained from 2( $\alpha, \beta$-dibromophenylpropionyl)phenylacetic acid by methanolysis with three equivalents of sodium methoxide and by carefully quenching the reaction mixture with diluted hydrochloric

* To whom correspondence should be addressed.

Abbreviations: CPD, 2-(1',3'-dioxo-3'-phenylpropyl)benzoic acid; CPP, 2-(3'-phenylpyrazol-5'-yl)benzoic acid; DPX-1840, 3,3a-dihydro-2-(4'-methoxyphẻnyl)-8H-pyrazolo[5,1- $a$ ]isoindol-8-one; NPA, $N$-1-naphthylphthalamic acid. 


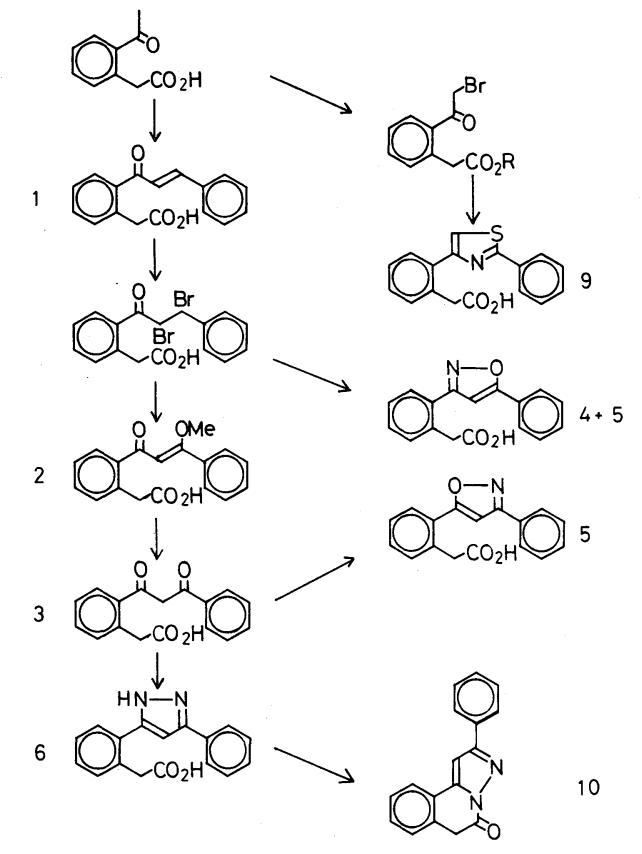

FIG. 1.

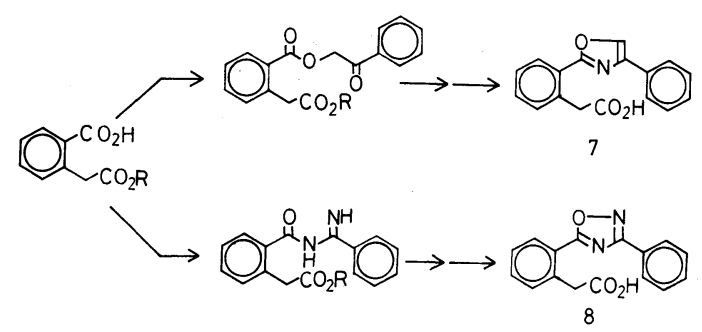

FIG. 2.

acid. 2-(5'-Phenylisoxazol-3'-yl)phenylacetic acid 4, was prepared from the dibromide and hydroxylamine under basic conditions. The isomer, 2-(3'-phenylisoxazol-5'-yl)phenylacetic acid 5, was also isolated as a minor product. The selective preparation of 5 was achieved by treatment of $2-\left(1^{\prime}, 3^{\prime}\right.$-dioxo- $3^{\prime}$ phenylpropyl)phenylacetic acid 3 with hydroxylamine hydrochloride in boiling pyridine. These isoxazole isomers were separable on an ODS column $\left(\mathrm{MeOH} / \mathrm{H}_{2} \mathrm{O}, 1: 1\right)$, and their EIMS spectra permitted the assignment of their structures. The base peak at $m / z 105$ in the spectrum of 4 and that at $m / z 103$ in the spectrum of 5 were assignable to the ions of benzaldehyde and benzonitrile, respectively. These ions are expected to be predominantly formed by electron impact on the molecules.

Condensation of 3 with hydrazine at room temperature gave 2-(3'-phenylpyrazol-5'-yl)phenylacetic acid 6, which was easily convertible by heat into the lactam, 2-phenyl-5 $\mathrm{H}$ pyrazolo[5,1-a]isoquinolin-5-one, 10.

Ethyl 2-(2'-phenyl-1', 3'-thiazol-4'-yl)phenylacetate was prepared by reaction of thiobenzamide with 2-bromoacetylphenylacetic acid by bromination in dry benzene. Hydrolysis, which was quantitatively obtained from 2-acetylphenylacetic acid of the ester furnished the carboxylic acid, 9.

Methyl 2-(phenacyloxycarbonyl)phenylacetate was prepared from the sodium salt of methyl hydrogen homophthalate and phenacyl bromide. Reaction of the phenacyl ester with ammonium acetate in acetic acid gave methyl 2-(4'-phenyloxazol-2'-yl)phenylacetate. Alkaline hydrolysis gave the corresponding acid, 7. Condensation of ethyl hydrogen homophthalate with benzamidine gave ethyl 2(benzamidinocarbonyl)phenylacetate, which was transformed to 2-( $3^{\prime}$-phenyl-1', $2^{\prime}, 4^{\prime}$ oxadiazol-5'-yl)phenylacetic acid, $\mathbf{8}$, by treatment with tert-butyl hypochlorite and sodium hydroxide.

\section{Biological activities}

Auxin transport inhibitors retard the growth of roots and stems of intact plants. First of all, the compounds, 5 and 12, the representatives of phenylacetic acids and auxin transport-inhibiting benzoic acids, respectively, were synthesized and their physiological properties were assessed on the growth of a few plants such as lettuce, rice, and buckwheat (Table I). The growth of roots of these seedlings were inhibited by the auxin transport inhibitor, 12, and also by the phenylacetic acid, $\mathbf{5}$, at the concentrations of 1 to $100 \mathrm{ppm}$, where the extent of inhibition was almost independent of the concentrations. At a level of $0.01 \mathrm{ppm}$ the phenylacetic acid had no effect on the growth of lettuce seedlings. The root growth of lettuce was less susceptible than those of rice and buckwheat. The growth of stems was differently affected by the acids. 
Table I. Growth-Regulating ACtivities of 2-(3'-PhenYlisoxazol-5'-Yl)PhenYlacetic ACID 5, AND THE CORRESPONDING BENZOIC ACID 12

\begin{tabular}{|c|c|c|c|c|c|c|c|}
\hline \multirow{3}{*}{ Compd. No. } & \multirow{3}{*}{$\begin{array}{l}\text { Conc. } \\
\text { (ppm) }\end{array}$} & \multicolumn{6}{|c|}{ Effects on growth ( $\%$ of control) ${ }^{a}$} \\
\hline & & \multicolumn{2}{|c|}{ Lettuce } & \multicolumn{2}{|c|}{ Rice } & \multicolumn{2}{|c|}{ Buckwheat } \\
\hline & & $\mathrm{R}^{b}$ & $\mathrm{~S}$ & $\mathrm{R}$ & $\mathbf{S}$ & $\mathrm{R}$ & $S$ \\
\hline 5 & $\begin{array}{c}100 \\
10 \\
1 \\
0.1 \\
0.01\end{array}$ & $\begin{array}{l}-40 \\
-34 \\
-24 \\
-26\end{array}$ & $\begin{array}{r}-52 \\
-52 \\
-53 \\
-45 \\
0\end{array}$ & $\begin{array}{l}-94 \\
-78 \\
-75\end{array}$ & $\begin{array}{l}-16 \\
+17 \\
+15\end{array}$ & $\begin{array}{l}-74 \\
-66 \\
-65\end{array}$ & $\begin{array}{l}-22 \\
-13 \\
+22\end{array}$ \\
\hline 12 & $\begin{array}{c}100 \\
10 \\
1 \\
0.1\end{array}$ & $\begin{array}{l}-37 \\
-26 \\
-30 \\
-35\end{array}$ & $\begin{array}{l}-44 \\
-53 \\
-34 \\
-7\end{array}$ & $\begin{array}{l}-84 \\
-82 \\
-82\end{array}$ & $\begin{array}{l}+7 \\
+20 \\
+22\end{array}$ & $\begin{array}{l}-66 \\
-64 \\
-63\end{array}$ & $\begin{array}{r}-3 \\
0 \\
+23\end{array}$ \\
\hline
\end{tabular}

a (-), inhibition; (+), stimulation.

b $\mathrm{R}$, root; $\mathrm{S}$, stem.

Compounds 5 and 12 were inhibitory to lettuce, rather stimulative to rice, and weakly inhibitory to buckwheat at a higher concentration while stimulative at a lower concentration. The phenylacetic acid showed antigeotropic activity on lettuce roots as well as the auxin transport-inhibiting benzoic acid that abolishes the root geotropic response of cress. ${ }^{9)}$ The prominant resemblance of their physiological effects on lettuce seedlings and of their structures suggested the possibility that the phenylacetic acid, 5, may achieve its physiological activities after being metabolized in tissues to the active benzoic acid, 12, or may be intrinsically an auxin transport inhibitor.

As shown in Table II, the growth of stems of intact lettuce seedlings was moderately inhibited by the other phenylacetic acids, 4, 6 10, which have a heterocyclic ring between the two benzene nuclei, at the concentrations of 0.1 to 100 ppm. However, 2-(1',3'-dioxo-3'-phenylpropyl)phenylacetic acid, 3 , only weakly inhibited the growth even at $100 \mathrm{ppm}$ and was rather stimulative at lower concentrations, while the corresponding benzoic acid (CPD), 11, retarded the growth to the same extent as the other benzoic acids. The $\alpha$-ketoene, 1 , and the $\beta$-ketoenol ether, $\mathbf{2}$, were stimulative or did not affect the growth at the concentrations tried. Except for compounds 1 and 2, all of the phenylacetic acids abolished the root geotropic response of lettuce seedlings. Compound 3 only weakly affected the geotropic response.

Since Katekar speculated that the growth inhibition of cress roots by the auxin transport inhibitors 11 and $\mathbf{1 2}$ may be related to the effect which causes inhibition of auxin transport in stems, ${ }^{9)}$ the auxin transport-inhibiting activities of compounds $3,5, \mathbf{1 1}$, and $\mathbf{1 2}$ were assessed in bean stem segments by the donorreceiver agar block technique. ${ }^{17)}$ All of the compounds inhibited the polar movement of auxin in bean stems (Table III). It seems curious that compound 3 , having a structure closely related to the auxin transport inhibitor 11, and inhibiting the auxin movement in bean although less effectively, did not retard the stem growth of lettuce and rather increased it as mentioned above. It is worthy of note that the phenylacetic acid, 5, more strongly inhibited the auxin transport than the corresponding benzoic acid, 12. This suggests that such a phenylacetic acid may be an intrinsic inhibitor of auxin transport without being oxidized to the corresponding benzoic acid, although the possibility of the oxidative activation in plant tissues is not excluded. From the above results, a heterocyclic ring such as isoxazole, diazole, 
Table II. Growth Regulating Activity IN LetTUCE STEMS

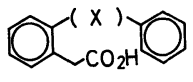

$1 \sim 9$

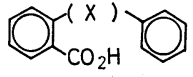

$11 \sim 13$

\begin{tabular}{|c|c|c|c|c|c|}
\hline \multirow{2}{*}{$\begin{array}{l}\text { Compd. } \\
\text { no. }\end{array}$} & \multirow{2}{*}{$X$} & \multicolumn{4}{|c|}{$\begin{array}{l}\text { Effects on growth } \\
( \pm \% \text { of control) }\end{array}$} \\
\hline & & 100 & 10 & 1 & $\left(\begin{array}{c}0.1 \\
\text { ppm })\end{array}\right.$ \\
\hline 1 & & & +30 & +15 & +18 \\
\hline 2 & & +1 & +1 & +4 & +1 \\
\hline 3 & & -18 & +13 & +23 & +13 \\
\hline 4 & & -54 & -55 & -59 & -22 \\
\hline 5 & & -52 & -52 & -53 & -45 \\
\hline 6 & & & -49 & -51 & -16 \\
\hline 7 & & & -53 & -49 & -16 \\
\hline 8 & & & -57 & -55 & -33 \\
\hline 9 & & -55 & -27 & -11 & -9 \\
\hline 10 & & -63 & -62 & -49 & +7 \\
\hline 11 & & & -51 & -39 & -17 \\
\hline 12 & & -44 & -53 & -34 & -7 \\
\hline 13 & & & -57 & -57 & -45 \\
\hline 14 & & & -61 & -33 & -10 \\
\hline
\end{tabular}

TABle III. IAA Transport Inhibiting ACtivity IN BEAN STEMS

Radioactivity (\%) of control

Compd. no.

Concentration of inhibitors in receiver block

$\begin{array}{llll}10^{-5} & 10^{-6} & 10^{-7} & 10^{-8}(\mathrm{M})\end{array}$

\begin{tabular}{rrrrr}
\hline $\mathbf{3}$ & 24 & 53 & 102 & \\
$\mathbf{5}$ & 2 & 8 & 34 & 83 \\
$\mathbf{1 1}$ & 9 & 24 & 41 & 57 \\
$\mathbf{1 2}$ & 6 & 28 & 73 & 109 \\
\hline
\end{tabular}

and thiazole may be a structural requirement for the dual activity of the auxin transportinhibiting phenylacetic acids.

\section{EXPERIMENTAL}

All melting points were uncorrected. The IR spectra were measured on a Shimadzu IR-420 spectrophotometer and the NMR were measured on a JEOL JNX-FX 100 spectrometer, using tetramethylsilane as an internal standard. Mass spectra were obtained on a ESCO EMD-05A mass spectrometer. The radioactivities were measured on an Aloka scintillation counter, LSC-900.

NPA was purchased from Tokyo Kasei Co., Ltd. and the other auxin transport-inhibiting benzoic acids were synthesized according to references $10 \sim 12$.

\section{Syntheses}

2-Cinnamoylphenylacetic acid (1). 2-Acetylphenylacetic $\operatorname{acid}^{13,14)}(8.9 \mathrm{~g})$ and benzaldehyde $(6.4 \mathrm{~g})$ were added to $100 \mathrm{ml}$ of aq. $10 \% \mathrm{NaOH}$ solution dropwise. After $2 \mathrm{hr}$, the mixture was acidified with dil. $\mathrm{HCl}$ and extracted with ether. The ether layer was washed with water and dried over $\mathrm{Na}_{2} \mathrm{SO}_{4}$. Evaporation of the solvent and crystallization from ether gave $1(10.1 \mathrm{~g}), \mathrm{mp} 107 \sim 109^{\circ} \mathrm{C}$. Found: C, 76.45; $\mathrm{H}, 5.30$, Calcd. for $\mathrm{C}_{17} \mathrm{H}_{14} \mathrm{O}_{3}: \mathrm{C}, 76.68$;

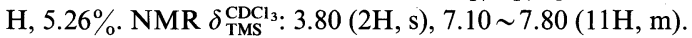
IR $v_{\max }^{\mathrm{KBr}} \mathrm{cm}^{-1}: 3000,2900,1710,1660,1600,1240,1220$.

2-( $\alpha, \beta$-Dibromophenylpropionyl)phenylacetic acid. Bromine $(2.23 \mathrm{~g})$ was added to a cold solution of $1(3.7 \mathrm{~g})$ in acetic acid $(50 \mathrm{ml})$ with stirring. After the reaction was completed, the solvent was removed. The residue was purified by crystallization from benzene to furnish $6.1 \mathrm{~g}$ of the acid, $\mathrm{mp} 155 \sim 158^{\circ} \mathrm{C}$. Found: $\mathrm{C}, 47.82 ; \mathrm{H}, 3.42$, Calcd. for $\mathrm{C}_{17} \mathrm{H}_{14} \mathrm{O}_{3} \mathrm{Br}_{2}: \mathrm{C}, 47.92 ; \mathrm{H}, 3.39 \%$. NMR $\delta_{\mathrm{TMS}}^{\mathrm{CDCl}_{3}}: 3.80$ $(2 \mathrm{H}, \mathrm{d}), 5.55(2 \mathrm{H}, \mathrm{dd}), 7.08 \sim 7.95(9 \mathrm{H}, \mathrm{m}) . \mathrm{IR} v_{\max }^{\mathrm{KBr}} \mathrm{cm}^{-1}$ : 3000, 2900, 1710, 1690, 1220.

2-( $\beta$-Methoxycinnamoyl)phenylacetic acid (2). 2-( $\alpha, \beta$ Dibromophenylpropionyl)phenylacetic acid $(1.07 \mathrm{~g})$ was added to a stirred solution of sodium methoxide $(0.17 \mathrm{~g}$ of $\mathrm{Na}$ in $20 \mathrm{ml}$ of $\mathrm{MeOH}$ ), and the mixture was refluxed for $1 \mathrm{hr}$. The reaction mixture was acidified with dil. $\mathrm{HCl}$ and extracted with AcOEt. After evaporating the solvent, an oily residue was put on a silica-gel column and eluted with ether. Evaporating the solvent and recrystallization from EtOH gave $2(0.2 \mathrm{~g}), \mathrm{mp} 122 \sim 124^{\circ} \mathrm{C}$. Found: $\mathrm{C}, 72.75 ; \mathrm{H}$, 5.60, Calcd. for $\mathrm{C}_{18} \mathrm{H}_{16} \mathrm{O}_{4}: \mathrm{C}, 72.96 ; \mathrm{H}, 5.44 \% \mathrm{NMR}$ $\delta_{\mathrm{TMS}}^{\mathrm{CDCl}_{3}}: 3.58(2 \mathrm{H}, \mathrm{s}), 3.85(3 \mathrm{H}, \mathrm{s}), 5.92(1 \mathrm{H}, \mathrm{s}), 7.00 \sim 7.60$ $(9 \mathrm{H}, \mathrm{m}) . \mathrm{IR} v_{\max }^{\mathrm{KBr}} \mathrm{cm}^{-1}: 3000,1700,1660,1550,1190$.

2-(1',3'-Dioxo-3'-phenylpropyl)phenylacetic acid (3). 2( $\alpha, \beta$-Dibromophenylpropionyl)phenylacetic acid $(7.2 \mathrm{~g})$ was added to a solution of sodium methoxide which was prepared from $1.4 \mathrm{~g}$ of $\mathrm{Na}$ and $40 \mathrm{ml}$ of abs. $\mathrm{MeOH}$, and the mixture was refluxed for $1 \mathrm{hr}$. After being cooled the solution was acidified with dil. $\mathrm{HCl}$ and left for $1 \mathrm{hr}$ and then extracted with AcOEt. The ethyl acetate solution was 
washed with water and dried over $\mathrm{Na}_{2} \mathrm{SO}_{4}$. Evaporating the solvent and recrystallizing the residues from benzene gave $3.3 \mathrm{~g}$ of $3(3.3 \mathrm{~g})$. mp $111 \sim 112^{\circ} \mathrm{C}$. Found: $\mathrm{C}, 72.07$; $\mathrm{H}, 5.10$, Calcd. for $\mathrm{C}_{17} \mathrm{H}_{14} \mathrm{O}_{4}$ : C, 72.33; $\mathrm{H}, 4.96 \%$. NMR $\delta_{\mathrm{TMS}}^{\mathrm{CDCl}_{3}}: 3.88(2 \mathrm{H}, \mathrm{s}), 6.64(1 \mathrm{H}, \mathrm{s}), 7.28 \sim 8.00(9 \mathrm{H}, \mathrm{m}) . \mathrm{IR}$ $v_{\max }^{\mathrm{KBr}} \mathrm{cm}^{-1}: 3000,1710,1600,1230$. MS $m / z: 264\left(\mathrm{M}^{+}-\right.$ $\mathrm{H}_{2} \mathrm{O}$ ), 120, 118, 105 (PhCO, base peak).

2-(5'-Phenylisoxazol-3'-yl)phenylacetic acid (4). 2-( $\alpha, \beta$ Dibromophenylpropionyl)phenylacetic acid (3.75g) and $\mathrm{NH}_{2} \mathrm{OH} \cdot \mathrm{HCl}(2.7 \mathrm{~g})$ were added to $10 \mathrm{ml}$ of aq. $40 \%$ $\mathrm{NaOH}$ solution. The mixture was heated with refluxing for $1 \mathrm{hr}$. After being cooled, the solution was acidified with dil. $\mathrm{HCl}$ and extracted with AcOEt. Washing with water, drying over $\mathrm{Na}_{2} \mathrm{SO}_{4}$, and evaporating the solvent gave crude products. Recrystallization from benzene gave 4 $(1.1 \mathrm{~g})$, mp $130 \sim 132^{\circ} \mathrm{C}$. Found: $\mathrm{C}, 72.73 ; \mathrm{H}, 4.78 ; \mathrm{N}, 4.84$, Calcd. for $\mathrm{C}_{17} \mathrm{H}_{13} \mathrm{O}_{3} \mathrm{~N}$ : C, 73.11; H, 4.66; N, 5.02\%. NMR

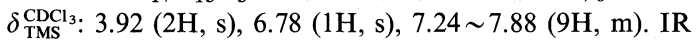
$v_{\max }^{\mathrm{KBr}} \mathrm{cm}^{-1}: 2900,1710,1570,1400,1240$. MS $m / z: 279$ $\left(\mathrm{M}^{+}\right), 262\left(\mathrm{M}^{+}-\mathrm{H}_{2} \mathrm{O}\right), 234\left(\mathrm{M}^{+}-\mathrm{CO}_{2} \mathrm{H}\right), 130,105$ (PhCO, base peak), 77.

2-(3'-Phenylisoxazol-5'-yl)phenylacetic acid (5). To a solution of $3(4.3 \mathrm{~g})$ in $20 \mathrm{ml}$ of pyridine, $2.3 \mathrm{~g}$ of $\mathrm{NH}_{2} \mathrm{OH}$. $\mathrm{HCl}$ was added. The mixture was boiled under refluxing for $1 \mathrm{hr}$. After cooling and acidification with dil. $\mathrm{HCl}$, the solution was extracted with AcOEt. The crude product was purified by recrystallization from benzene to give $2.7 \mathrm{~g}$ of 5, $120 \sim 123^{\circ} \mathrm{C}$. Found: $\mathrm{C}, 72.78 ; \mathrm{H}, 4.86 ; \mathrm{N}, 5.02$, Calcd. for $\mathrm{C}_{17} \mathrm{H}_{13} \mathrm{O}_{3} \mathrm{~N}$ : C, 73.11; H, 4.66; N, 5.02\%. NMR $\delta_{\mathrm{TMS}}^{\mathrm{CDCl}_{3}:} 3.92(2 \mathrm{H}, \mathrm{s}), 6.80(1 \mathrm{H}, \mathrm{s}), 7.23 \sim 7.90(9 \mathrm{H}, \mathrm{m}) . \mathrm{IR}$ $v_{\max }^{\mathrm{KBr}} \mathrm{cm}^{-1}: 2900,1720,1610,1570,1410,1170$. MS $\mathrm{m} / \mathrm{z}$ : $279\left(\mathrm{M}^{+}\right), 234\left(\mathrm{M}^{+}-\mathrm{CO}_{2} \mathrm{H}\right), 118,103(\mathrm{PhCN}$, base peak), 77.

2-(3'-Phenylpyrazol-5'-yl)phenylacetic acid(6). To a solution of $3(1.41 \mathrm{~g})$ in $10 \mathrm{ml}$ of $\mathrm{EtOH}, 0.25 \mathrm{~g}$ of hydrazine hydrate was added, and then the solution was left at room temperature for $5 \mathrm{hr}$. After acidification with dil. $\mathrm{HCl}$ the solution was extracted with ether. The ether was washed with water and dried over $\mathrm{Na}_{2} \mathrm{SO}_{4}$. Evaporating ether gave $6(0.78 \mathrm{~g}), \mathrm{mp} 135 \sim 140^{\circ} \mathrm{C}$. Found: $\mathrm{C}, 73.05 ; \mathrm{H}, 4.85$; $\mathrm{N}, 9.98$, Calcd. for $\mathrm{C}_{17} \mathrm{H}_{14} \mathrm{O}_{2} \mathrm{~N}_{2}: \mathrm{C}, 73.38 ; \mathrm{H}, 5.04 ; \mathrm{N}$, 10.07. NMR $\delta_{\mathrm{TMS}}^{\mathrm{CDCl}_{3}:} 3.80(2 \mathrm{H}, \mathrm{s}), 6.71(1 \mathrm{H}, \mathrm{s}), 7.30 \sim 7.83$ $(9 \mathrm{H}, \mathrm{m}) . \mathrm{IR} v_{\max }^{\mathrm{KBr}} \mathrm{cm}^{-1}: 3400,3000,1710,1570,1450 . \mathrm{MS}$ $m / z: 260\left(\mathrm{M}^{+}-\mathrm{H}_{2} \mathrm{O}\right.$, base peak $), 232\left(\mathrm{M}^{+}-\mathrm{CO}_{2} \mathrm{H}_{2}\right), 129$, 77.

2-Phenyl-5H-pyrazolo[5,1-a]isoquinolin-5-one (10). Hydrazine hydrate $(0.25 \mathrm{~g})$ was added to a solution of 3 $(1.41 \mathrm{~g})$ in $10 \mathrm{ml}$ of EtOH and the mixture was refluxed for $2 \mathrm{hr}$. After cooling the reaction mixture, crystalline precipitates were collected and recrystallized from acetic acid to give $1 \mathrm{~g}$ of $10, \mathrm{mp} 185 \sim 187^{\circ} \mathrm{C}$. Found: $\mathrm{C}, 78.51 ; \mathrm{H}, 4.65$; $\mathrm{N}, 10.62$, Calcd. for $\mathrm{C}_{17} \mathrm{H}_{12} \mathrm{ON}_{2}: \mathrm{C}, 78.44 ; \mathrm{H}, 4.65 ; \mathrm{N}$,

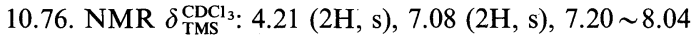
$(9 \mathrm{H}, \mathrm{m})$. IR $v_{\max }^{\mathrm{KBr}} \mathrm{cm}^{-1}: 1730,1600,1330,1310$. MS $\mathrm{m} / \mathrm{z}$ : $260\left(\mathrm{M}^{+}\right), 232\left(\mathrm{M}^{+}-\mathrm{CO}\right), 129$ (base peak), 77.

2-(Bromoacetyl)phenylacetic acid. 2-Acetylphenylacetic acid $^{14)}$ was dissolved in $150 \mathrm{ml}$ of $\mathrm{AcOH}$ and treated with bromine. After addition of the first few drops of bromine, the flask was warmed to start the reaction. When the solution had decolorized, the remaining bromine was rapidly added dropwise under stirring. Stirring was continued further $5 \mathrm{~min}$ after addition completed, then the solvent was removed under reduced pressure. The syrupy residue was crystallized from hexane by trituration. The crude product $(4.6 \mathrm{~g})$ was used for the next reaction without further purification, $\mathrm{mp} 163 \sim 165^{\circ} \mathrm{C}$. NMR $\delta_{\mathrm{TMS}}^{\mathrm{CDCl}_{3}}$ $\mathrm{cm}^{-1}: 3.84(2 \mathrm{H}, \mathrm{s}), 4.52(2 \mathrm{H}, \mathrm{s}), 7.10 \sim 7.74(4 \mathrm{H}, \mathrm{m})$.

Ethyl 2-(2'-phenylthiazol-4'-yl)phenylacetate. A solution of thiobenzamide $(2.45 \mathrm{~g})$ and 2-(bromoacetyl)phenylacetic acid $(2.57 \mathrm{~g})$ in $50 \mathrm{ml}$ of EtOH was heated to reflux for $24 \mathrm{hr}$. The solvent was removed under reduced pressure and the residues were recrystallized from aq. EtOH to give colorless needles of mp $76 \sim 78^{\circ} \mathrm{C}$, yield $2.45 \mathrm{~g}$. NMR $\delta_{\mathrm{TMS}}^{\mathrm{CDCl}_{3}}: 1.04(3 \mathrm{H}, \mathrm{t}), 3.85(2 \mathrm{H}, \mathrm{s}), 3.95(2 \mathrm{H}, \mathrm{q}), 7.00 \sim 7.94$ $(10 \mathrm{H}, \mathrm{m})$. IR $v_{\max }^{\mathrm{KBr}} \mathrm{cm}^{-1}: 1740,1480,1160$.

2-(2'-Phenylthiazol-4'-yl)phenylacetic acid (9). The foregoing ethyl ester $(0.9 \mathrm{~g})$ dissolved in $10 \mathrm{ml}$ of $\mathrm{EtOH}$ containing $2 \mathrm{ml}$ of aq. $10 \% \mathrm{NaOH}$ solution was heated to reflux for $1 \mathrm{hr}$. The reaction mixture was poured into water and acidified with dil. $\mathrm{HCl}$. Upon chilling the solution, the acid 9 precipitated as fine colorless needles $(0.78 \mathrm{~g}), \mathrm{mp}$ $108 \sim 110^{\circ} \mathrm{C}$. Found: C, 68.94; H, 4.49; N, 4.76, Calcd. for $\mathrm{C}_{17} \mathrm{H}_{13} \mathrm{O}_{2} \mathrm{NS}: \mathrm{C}, 69.13 ; \mathrm{H}, 4.43 ; \mathrm{N}, 4.74 \%$. NMR $\delta_{\mathrm{TMS}}^{\mathrm{CDCl}_{3}}$ : $3.70(2 \mathrm{H}, \mathrm{s}), 7.10 \sim 7.90(10 \mathrm{H}, \mathrm{m})$. IR $v_{\max }^{\mathrm{CDCl}_{3}} \mathrm{~cm}^{-1}: 3000$, 2600, 1730, 1480. MS $m / z: 295\left(\mathrm{M}^{+}\right), 251\left(\mathrm{M}^{+}-\mathrm{CO}_{2}\right)$, 148, 147, 121 (PhCS, base peak), 104, 103 (PhCN), 77.

Methyl 2-(phenacyloxycarbonyl)phenylacetate. Methyl hydrogen homophthalate $\left.{ }^{15}\right)(1.94 \mathrm{~g})$ and phenacyl bromide $(1.99 \mathrm{~g})$ was dissolved in $10 \mathrm{ml}$ of dimethylformamide and $\mathrm{Na}_{2} \mathrm{CO}_{3}(1.1 \mathrm{~g})$ was added. After heating at $100^{\circ} \mathrm{C}$ for $1 \mathrm{hr}$, the reaction mixture was diluted with water and extracted with ether. Washing with water, drying over $\mathrm{Na}_{2} \mathrm{SO}_{4}$, evaporating the solvent, and recrystallizing from EtOH gave $2.53 \mathrm{~g}$ of the ester, mp $88 \sim 90^{\circ} \mathrm{C}$. Found: $\mathrm{C}, 69.06 ; \mathrm{H}$, 5.12, Calcd. for $\mathrm{C}_{18} \mathrm{H}_{16} \mathrm{O}_{5}: \mathrm{C}, 69.22 ; \mathrm{H}, 5.16 \% \mathrm{NMR}$ $\delta_{\mathrm{TMS}}^{\mathrm{CDCl}_{3}}: 3.65(3 \mathrm{H}, \mathrm{s}), 4.05(2 \mathrm{H}, \mathrm{s}), 5.53(2 \mathrm{H}, \mathrm{s}), 7.18 \sim 8.22$ $(9 \mathrm{H}, \mathrm{m})$. IR $v_{\max }^{\mathrm{KBr}} \mathrm{cm}^{-1}: 1740,1720,1700,1270,1230,1220$.

Methyl 2-(4'-phenyloxazol-2'-yl)phenylacetate. Methyl 2-(phenacyloxycarbonyl)phenylacetate $(1.2 \mathrm{~g})$ and ammonium acetate $(2.4 \mathrm{~g})$ was dissolved in acetic acid and heated to reflux for $3 \mathrm{hr}$. Then the mixture was extracted with AcOEt after adding water. The ethyl acetate layer was washed with $5 \% \quad \mathrm{Na}_{2} \mathrm{CO}_{3}$ and dried over $\mathrm{Na}_{2} \mathrm{SO}_{4}$, then the solvent was evacuated. The methyl ester was separated through a silica-gel column by eluting with hexane-ether and recrystallized from EtOH to give $80 \mathrm{mg}$

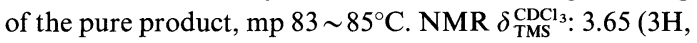
s), $4.24(2 \mathrm{H}, \mathrm{s}), 7.20 \sim 8.10(10 \mathrm{H}, \mathrm{m}) . \mathrm{IR} v_{\max }^{\mathrm{KBr}} \mathrm{cm}^{-1}: 1730$, 1490, 1430, 1350, 1170.

2-(4'-Phenyloxazol-2'-yl)phenylacetic acid (7). The foregoing methyl ester $(50 \mathrm{mg})$ was dissolved in $1 \mathrm{ml}$ of $\mathrm{EtOH}$ containing $0.2 \mathrm{ml}$ of $10 \%$ aq. solution of $\mathrm{NaOH}$ and heated to reflux for $1 \mathrm{hr}$. The mixture was poured into water and acidified with dil. $\mathrm{HCl}$, and then extracted with 
AcOEt. After evaporating the solvent, the residue was recrystallized from EtOH to give $30 \mathrm{mg}$ of $7, \mathrm{mp} 159$ $160^{\circ} \mathrm{C}$. Found: C, 72.59; H, 4.74; N, 4.89, Calcd. for

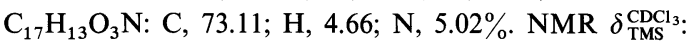
$4.02(2 \mathrm{H}, \mathrm{s}), 7: 20 \sim 8.10(1 \mathrm{H}, \mathrm{m})$. IR $v_{\max }^{\mathrm{KBr}} \mathrm{cm}^{-1}: 3000$, $1700,1490,1410,1340,1240$. MS $m / z: 279\left(\mathrm{M}^{+}\right), 235$ $\left(\mathrm{M}^{+}-\mathrm{CO}_{2}\right), 208,118,102,89\left(\mathrm{C}_{7} \mathrm{H}_{5}\right.$, base peak $), 77$.

Ethyl 2-(benzamidinocarbonyl)phenylacetate. To a stirred solution of ethyl hydrogen homophthalate ${ }^{16)}(3.04 \mathrm{~g})$ in dichloromethane, $3.31 \mathrm{~g}$ of DCC was added. After $30 \mathrm{~min}, 1.77 \mathrm{~g}$ of benzamidine was added and the mixture was left at room temperature for $12 \mathrm{hr}$, then the precipitate of DCU was filtered off. After evaporating the solvent, the residue was chromatographed on a silica-gel column by using $\mathrm{CH}_{2} \mathrm{Cl}_{2}$ as a mobile phase. Yield $0.62 \mathrm{~g}$. NMR $\delta_{\mathrm{TMS}}^{\mathrm{CDCl}_{3}}$ : $1.16(3 \mathrm{H}, \mathrm{t}), 4.06(2 \mathrm{H}, \mathrm{q}), 7.10 \sim 8.40(9 \mathrm{H}, \mathrm{m})$.

2-(3'-Phenyl-1',2',4'-oxadiazol-5'-yl)phenylacetic acid (8). tert-Butyl hypochlorite $(0.24 \mathrm{~g})$ was gradually added to a stirred suspension of ethyl 2-(benzamidinocarbonyl)phenylacetate $(0.62 \mathrm{~g})$ in $\mathrm{EtOH}$ at $0 \sim 5^{\circ} \mathrm{C}$. After $30 \mathrm{~min}$ of stirring at this temperature, $5 \mathrm{ml}$ of $2 \mathrm{~N} \mathrm{NaOH}$ was added to the solution. The mixture was warmed at $70^{\circ} \mathrm{C}$ for $40 \mathrm{~min}$. After acidification with dil. $\mathrm{HCl}$, the mixture was extracted with AcOEt. The acid was isolated by column chromatography. Recrystallization from benzene gave $86 \mathrm{mg}$ of 8, mp $178 \sim 180^{\circ} \mathrm{C}$. Found: C, $68.02 ; \mathrm{H}, 4.59 ; \mathrm{N}$, 9.31, Calcd. for $\mathrm{C}_{16} \mathrm{H}_{12} \mathrm{O}_{3} \mathrm{~N}_{2}: \mathrm{C}, 68.57 ; \mathrm{H}, 4.32 ; \mathrm{N}, 9.99 \%$. NMR $\delta_{\mathrm{TMS}}^{\mathrm{CDCl}_{3}}: 4.15(2 \mathrm{H}, \mathrm{s}), 7.12 \sim 8.25(9 \mathrm{H}, \mathrm{m})$. IR $v_{\max }^{\mathrm{KBr}}$ $\mathrm{cm}^{-1}: 3000,1710,1610,1560,1360,1240$. MS $m / z: 280$ $\left(\mathrm{M}^{+}\right), 262\left(\mathrm{M}^{+}-\mathrm{H}_{2} \mathrm{O}\right), 234,178,163,135,118,89\left(\mathrm{C}_{7} \mathrm{H}_{5}\right.$, base peak), 77 .

Plant growth-regulating activity. One $\mathrm{ml}$ of acetone solution of a compound to be tested was poured on to the filter paper in a Petri dish (diameter $9 \mathrm{~cm}$ ). After evaporating the solvent, $10 \mathrm{ml}$ of water was added. Seeds ( 20 for lettuce, 12 for rice and buckwheat) were cultured in a growth room (8 PPFD, $\mathrm{nEcm}{ }^{-2} \mathrm{sec}^{-1}, 12 \mathrm{hr}$ photoperiod, rel. humidity $60 \pm 5 \%$, temp. $25 \pm 1{ }^{\circ} \mathrm{C}$ ). Growth-regulating activities were evaluated after 5 days by inspecting the rates of growth inhibition or stimulation of stems and roots. The rates were indicated by percentages of the averaged lengths of stems or roots of treated plants to those of controls.

Auxin transport-inhibiting activity. The auxin trasportinhibiting activities of several phenylacetic acids and benzoic acids were measured by Keitt and Baker's method ${ }^{17)}$ using excised tissue sections of bean seedlings (Phaseolus vulgaris $\mathrm{L}$. var. America).

Plant materials. Plants were grown in a growth cabinet (fluorescent lamp $40 \mathrm{~W} \times 2 ; 12 \mathrm{hr}$ photoperiod; relative humidity $60 \pm 5 \%$; temperature $25 \pm 1^{\circ} \mathrm{C}$ ) in trays containing vermiculite, and were watered daily. After 13 days the primary leaves had expanded and a few $\mathrm{cm}$ of shoot had grown above the primary nodes. Sections $13 \mathrm{~mm}$ long were taken beginning $3 \mathrm{~mm}$ below the primary node by a double-bladed cutter and cutting guide. A tiny ink mark was placed near the apical end before cutting.

Transport inhibition experiment. Jigs were constructed to hold 20 bean epicotyl sections which were placed with the basal end resting on a receiver agar disc ( $24 \mathrm{~mm}$ diameter, $0.5 \mathrm{ml}$ of $0.5 \%$ agar) containing a test compound at the required concentration. A donor disc (same as receiver) containing IAA-2 $-{ }^{14} \mathrm{C}$ (sp. act. $30 \mathrm{mCi} / \mathrm{mmol}, \mathrm{CEA}$ ) at $1 \mathrm{ppm}$ concentration was placed on the apical end of each set of 20 sections, and the assembly was placed in a moist chamber to allow transport for $4 \mathrm{hr}$. After this period the radioactivity in the basal disc was measured on an Aloka scintillation counter (LSC-900). Acropetal movement of IAA, which was measured by setting the receiver and donor discs in reverse, was $13 \%$ of the basal movement in the control experiment. At least three replications per concentration were done.

\section{REFERENCES}

1) E. M. Beyer, Jr., Plant Physiol., 50, 322 (1972).

2) .E. M. Beyer, Jr., A. L. Johnson and P. B. Sweetser, Plant Physiol., 57, 839 (1976).

3) P. M. Morgan and J. I. Durhan, Plant Physiol., 50, 313 (1972).

4) L. D. Nooden and S. M. Nooden, Plant Physiol., 78, 263 (1985).

5) G. F. Katekar, Phytochemistry, 15, 1421 (1976); T. Teitei, Agric. Biol. Chem., 47, 1461 (1983).

6) G. F. Katekar and A. E. Geissler, Plant Physiol., 60, 826 (1977).

7) F. Wightman and D. L. Lighty, Physiol. Plant., 55, 17 (1982).

8) N. B. Mandava, R. G. Orellena, J. D. Warthen, Jr., J. F. Worley, S. R. Dutky, H. Finegold and B. C. Weathington, J. Agric. Food Chem., 26, 71 (1980).

9) G. F. Katekar and A. E. Geissler, Plant Physiol., 66, 1190 (1980).

10) B. T. Brown and O. Johnasen, Pestic. Sci., 4, 473 (1973).

11) R. L. N. Harris and J. L. Huppatz, Aust. J. Chem., 30, 2225 (1977).

12) A. E. Geissler, J. L. Huppatz and G. F. Katekar, Pestic. Sci., 6, 441 (1975).

13) M. Makosza, Tetrahedron Lett., 1966, 4621.

14) J. O. Halford and B. Weissmann, J. Org. Chem., 18, 30 (1953).

15) L. F. Fieser and M. M. Pechet, J. Am. Chem. Soc., 68, 2577 (1946).

16) W. R. H. Hurtley, J. Chem. Soc., 1929, 1870.

17) G. W. Keitt, Jr. and R. A. Baker, Plant Physiol., 41, 1561 (1966). 